Психолого-педагогічні проблеми становлення сучасного фахівця Випуск 2018

УДК 005.963.1::37.011.3-051:001.83]:37.091.212.3

DOI 10.26697/9786177089017.2018.149

\author{
Малихіна Олена Євгенівна \\ Харківський національний педагогічний університет \\ імені Г. С. Сковороди

\section{ПІДГОТОВКА МАЙБУТНІХ ВЧИТЕЛІВ ДО РОБОТИ З ОБДАРОВАНИМИ УЧНЯМИ}

(C) Малихіна О. Є., 2018

В статті актуалізовано необхідність формування готовності майбутніх вчителів до роботи з обдарованими дітьми. Розглянуто ї̈ сутність, структурні компоненти та шляхи формування. Акиентовано увагу на якостях, необхідних педагогу для роботи 3 обдарованими учнями.

Ключові слова: обдаровані учні, професійно-педагогічна компетентність, готовність до роботи з обдарованими учнями.

Проблема, їі зв'язок із важливими науковими та практичними завданнями. Одним 3 найважливіших завдань, що стоять перед сучасною школою, $\epsilon$ максимально повне розкриття можливостей кожного учня, й особливо обдарованих дітей, які мають потенціал до високих досягнень в різних сферах діяльності. Підвищення інтересу до розвитку обдарованих школярів зумовлено тим, що саме 3 ними суспільство та держава пов'язують перспективи розвитку науки, техніки, культури, мистецтва. В той же час, як відмічають дослідники, спостерігається суперечність між соціальною потребою в розвитку обдарованих учнів та відсутністю системи цілеспрямованої підготовки майбутніх педагогів до роботи 3 даною категорією дітей.

Аналіз публікацій (виділення невирішених проблем). Проблема обдарованості та розвитку здібних учнів неодноразово ставала предметом багатьох психолого-педагогічних досліджень як у зарубіжній (Дж. Гілфорд, С. Меднік, Е. Торренс, Дж. Рензуллі), так і у вітчизняній науці (В. Дружинін, Н. Лейтес, О. Матюшкін, В. Моляко, Б. Теплов, М. Холодна), в яких розглядалася у різних аспектах, а саме: вивчалися поняття обдарованості та iï види, теорії обдарованості, вікові та психологічні особливості обдарованих дітей, підходи до їх навчання та виховання, методи розвитку здібностей до різних видів діяльності, методи діагностики обдарованості тощо [1-3]. Актуальним, але найменш вивченим питанням проблеми розвитку обдарованої особистості, $\epsilon$ формування готовності майбутніх педагогів до роботи зі здібними школярами. Проблема підготовки як майбутніх, так i 


\section{Збірник наукових статей}

працюючих вчителів до роботи з обдарованими учнями підіймалося у працях вітчизняних вчених (О. Антонова, В. Демченко, О. Жосан, А. Крикун, Л. Мерва, М. Шемуда). В їх дослідженнях [4] розкрито деякі аспекти формування готовності вчителів до роботи зі здібними та обдарованими школярами, але переважно в системі післядипломної педагогічної освіти. Питання формування готовності до роботи 3 обдарованими школярами у майбутніх педагогів залишається недостатньо вивченим.

Ціль статті - аналіз та узагальнення психолого-педагогічних досліджень щодо підготовки майбутніх вчителів до роботи 3 обдарованими учнями.

Виклад основного матеріалу, обгрунтування результатів дослідження. Сучасні дослідження, що присвячені проблемі формування готовності педагогів до роботи зі здібними та обдарованими учнями, зосереджені на вивченні таких аспектів, як визначення іiі сутності, виокремлення структурних компонентів та визначення можливих шляхів формування тощо.

Так, дослідники О. Жосан, М. Шемуда розглядають готовність вчителя до роботи з обдарованими учнями як складову професійнопедагогічної компетенції, під якою розуміють єдність теоретичної та практичної готовності до здійснення педагогічної діяльності. До цієї точки зору наближуються погляди $\mathrm{B}$. Демченко, яка розглядає готовність педагога до роботи з обдарованими учнями як результат спеціальної підготовки, комплекс набутих особистісних та професійних якостей, що охоплюють специфічні знання, вміння, навички, риси характеру, мотиваційні характеристики, особисті здібності, що надають можливості виявляти, розвивати творчі задатки школярів. В якості компонентів авторкою виокремлюються наступні: мотиваційний, особистісний, змістовий процесуальний та креативний.

У дослідженнях О. Жосан, В. Литвиненко, Л. Рибалко виокремлено структурні компоненти готовності, які можуть виступати критеріями щодо визначення рівнів іiі сформованості: позитивна мотивація (мотиваційно-вольовий критерій), рівень професійної компетентності (інтелектуально-операційний критерій), рефлексія i корекція (оцінювально-рефлексивний критерій). Мотиваційновольовий критерій включає професійну спрямованість та особистісні якості, що характеризують придатність фахівця здійснювати роботу з розвитку здібностей учнів. Інтелектуально-операційний - передбачає наявність певного рівня професійної компетентності, необхідних загальних гуманітарних і спеціальних знань 3 теорії та методики навчально-виховної роботи. Оцінювально-рефлексивний - аналіз результатів своєї діяльності, усвідомлення ним свого рівня професійної підготовки до реалізації мети і завдань роботи. 
На основі аналізу дисертаційних досліджень В. Ушмарова [5] зазначає, що більшості вчителів не вистачає як теоретичних знань стосовно проявів обдарованості, так і практичної підготовки щодо діагностики, ідентифікації та розвитку обдарованих учнів. На важливість наявності теоретичних знань про сутність та специфіку обдарованості, методи іiі діагностики та умінь їх використовувати, організовувати процес навчання 3 використанням інноваційних технологій вказують також О. Антонова, К. Пажитнєва, І. Ушатікова.

3 нашої точки зору, такий підхід до структури готовності вчителів до роботи 3 обдарованими учнями є більш оптимальним. Необхідність теоретичної підготовки пояснюється специфікою вікового та індивідуального розвитку обдарованих дітей. А саме їх відрізняє особлива потреба у розумовому пошуку, розумовому навантаженні, що характеризується: активністю (людина сама шукає зміну вражень, нову інформацію, відчуває потребу в самому процесі пізнання; ненасиченістю; задоволенням від розумової праці). Також у розвитку пізнавальної сфери обдарованим дітям притаманні надчутливість до проблем, надситуативна активність, підвищений інтерес до дивергентних задач, оригінальність та гнучкість мислення, легкість генерування ідей, здатність до прогнозування, висока концентрація уваги, відмінна пам'ять та багатий словниковий запас. Розвиток особистості обдарованих характеризується певною диссинхронією, що виявляється у феномені соціального, емоційного та моторного дисбалансів. Практична підготовка майбутніх вчителів до роботи зі здібними учнями передбачає оволодіння методами діагностики обдарованості та методами їі розвитку.

Особливу увагу дослідники приділяють питанню сформованості якостей самого педагога. Так, М. Карне виокремлює якості, що необхідні вчителю для роботи з обдарованими дітьми: реалістична, позитивна «Я»-концепція; чуйність та доброзичливість; активний, жвавий характер; почуття гумору; гнучкість, готовність переглядати свої погляди; творчий світогляд; високий рівень інтелекту; спеціальні здібності в галузі мистецтва; інтелектуальна гнучкість; широке коло інтересів; наполегливість; емоційна стійкість; демократичний стиль спілкування; готовність до виконання різних обов'язків, пов'язаних 3 навчанням обдарованих дітей.

Формування готовності педагогів до роботи зі здібними та обдарованими учнями передбачає, в першу чергу, ознайомлення 3 особливостями їх психічного розвитку. 3 цією метою на факультеті початкового навчання ХНПУ імені Г. С. Сковороди запроваджено спецкурс «Психологія обдарованої дитини», що спрямований на виклад знань про психологічні особливості обдарованих дітей, вікову динаміку їх психічного розвитку, проблеми їх навчання та виховання. 


\section{Збірник наукових статей}

У дисципліні розглядаються: загальні питання психології дитячої обдарованості, їі види, методи діагностики та розвитку обдарованості; проблеми біологічної та соціальної обумовленості обдарованості; співвідношення загальної і спеціальної обдарованості; врахування особливостей обдарованих дітей у навчально-виховному процесі; принципи, засоби і методи організації навчання i виховання обдарованих дітей в сім'ї, в загальноосвітній школі, в спеціальних закладах освіти; основи психологічної діагностики обдарованих дітей; особливості контролю та керування навчально-виховним процесом при роботі з обдарованими дітьми. Оволодіння знаннями зі спецкурсу «Психологія обдарованої дитини», 3 нашої точки зору, сприяє формуванню теоретичної та практичної готовності студентів до роботи 3 дітьми, що мають потенціал до високих досягнень у різних видах діяльності.

Висновки. Отже, аналіз досліджень з даної проблеми, показує, що більшість дослідників об'єднує виділення в якості основних наступних компонентів: теоретична готовність (наявність знань про особливості обдарованих школярів), практична готовність (наявність умінь виявляти здібних учнів та сприяти їх розвитку), психологічна (наявність певних якостей особистості). Однією 3 форм підготовки майбутніх вчителів до роботи 3 обдарованими школярами $\epsilon$ запровадження спецкурсів, що надають знання про психологічні й вікові особливості обдарованих дітей, проблеми, що виникають в процесі їх розвитку, специфіку їх навчання та виховання.

\section{Література}

1. Ильин Е. П. Психология творчества, креативности, одаренности / Е. П. Ильин. - СПб. : Питер. - 2011. - 448 с.

2. Психология одаренности детей и подростков / Под ред. Н. С. Лейтеса. - М. : Издательский центр «Академия». - 1996. - 416 с.

3. Kushch O. Cognitive processes as a factor of the development of literary and creative talents in children / O. Kushch, O. Malykhina, J. Gregor // Littera scripta. Journals of the Institute of Technology and Business in Česke Budějovise. - 2017. - № 1. - P. 62-71.

4. Крикун А. Ю. Формування професійної готовності педагогів до роботи 3 обдарованими дітьми в системі післядипломної педагогічної освіти / А. Ю. Крикун // Освіта та розвиток обдарованої особистості. - 2013. - № 1. - С. 60-62.

5. Ушмарова В. В. Сучасні тенденції формування готовності вчителів початкової школи до роботи зі здібними та обдарованими учнями / В. В. Ушмарова // Засоби навчальної та науково-дослідної роботи. - 2014. - № 42. - С. 141-148. 
Психолого-педагогічні проблеми становлення сучасного фахівця Випуск 2018

\section{Елена Малыхина. Подготовка будущих учителей к работе с одаренными учащимися.}

B cтатье актуализируется необходимость формирования готовности будущих педагогов $к$ работе $c$ одаренными детьми. Рассматриваются ее сущуность, структурные компоненты и пути формирования. Акцентируется внимание на качествах, необходимых педагогу для работы с одаренными учашимися.

Ключевые слова: одаренные учащчиеся, профессиональнопедагогическая компетентность, готовность к работе с одаренными учениками.

\section{Olena Malykhina. Preparation of future teachers for work with gifted students. \\ The need to form the readiness of future teachers to work with gifted children has been updated. The essence, structural components and ways of formation have been considered. Attention was focused on the qualities necessary for the teacher to work with gifted pupils.}

Keywords: gifted pupils, professional-pedagogical competence, readiness to work with gifted pupils.

Стаття надійшла до редакційної колегії 07.05.2018

Прийнято до друку 08.05.2018

\section{Інформація про автора:}

Малихіна Олена Євгенівна - кандидат психологічних наук, доцент кафедри філософсько-психологічної антропології, Харківський національний педагогічний університет імені Г. С. Сковороди. 